\title{
Assessment of seat belt use and its associated factors among public transport drivers in North Gondar, Ethiopia: a cross-sectional study
}

\author{
Manay K. Woldegebriel ${ }^{1}$, Berihu G. Aregawi ${ }^{1}$ and Hafte T. Gebru ${ }^{2^{*}}$
}

\begin{abstract}
Objective: Road traffic injuries are the major and neglected public health challenges. It causes 1.2 million deaths and 50 million injuries yearly and the use of seat belt reduces $60 \%$ of the cases. However, little is known about the magnitude of utilizing seat belt and associated factors in Ethiopia. Hence, the aim of this study was to assess the seat belt practice and associated factors among minibus and taxi drivers.

Results: The magnitude of seat belt users is $69.6 \%$. The majority (98.1\%) of drivers used seat belt to minimize injuries, $95.8 \%$ to prevent casualties, $92.5 \%$ to safeguard vehicle occupants, $29.9 \%$ to generate revenue for government and $22.8 \%$ to beautify the vehicle. Almost $80 \%$ of participants reported that wearing seat belt could save lives; and $29.6 \%$ of them wear belts because of stiffer penalties. For not using seat belts, more than $18 \%$ drivers reasoned out that it is not guarantee for safety and it wastes time to wear. In the multiple logistic regression being taxi driver $(A O R=1.998$, $95 \% \mathrm{Cl} 1.250,3.192)$, being married $(\mathrm{AOR}=2.91,95 \% \mathrm{Cl} 1.118,7.601)$ and attended vocational school and above $(A O R=2.140,95 \% \mathrm{Cl} 1.014,4.519)$ were associated with seat belt use.
\end{abstract}

Keywords: Drivers, Ethiopia, Knowledge, Seat belt use

\section{Introduction}

Road traffic injuries are a major and neglected public health challenge that requires intensive efforts for effective and sustainable prevention. According to the World Health Organization (WHO) report, 1.2 million peoples die and 50 million get injured from road traffic crashes every year [1]. It will be the third leading contributor to the global burden of disease and injury by 2020 [2, 3]. Most of (91\%) road deaths occurred in low and middle income countries [4].

In the case of Africa, road traffic accidents constitute $25 \%$ of all injury related deaths [5] and over $75 \%$ of road traffic casualties are in the economic productive age of 16-65 years. In Ethiopia, it is the cause of significant

\footnotetext{
*Correspondence: haftishkind@gmail.com

${ }^{2}$ Department of Biomedical Sciences, College of Health Sciences and Referral Hospital, Aksum University, P.O.Box: 298, Aksum, Ethiopia

Full list of author information is available at the end of the article
}

losses of human and economic resources. In 2014/2015 Ethiopian police reported 15,086 accidents which caused the losses of 2161 lives and over US\$ 7.3 million. The Ethiopian National Road Safety Coordination Office cites a road crash fatality rate of 114 deaths per 10,000 vehicles per year and the real figure may be higher as there may be underreporting [6]. Study done in Ethiopia, on the road from Addis Ababa to Adama/Hawassa showed that the fatality rate of car accident was 156 per 10,1000 vehicles [7]. A study in Amhara region between 2007 and 2011, shows that there were 10,162 road traffic accidents, claiming the lives of 2761 people, injuring 3890 people and caused property damage of 4,755,514 USD [8].

Injury control is a public health problem and we have an ethical responsibility to arrange for the safety of individuals [9]. Seat belt use prevents and reduces the severity of injuries during motor vehicle crashes [10, 11]. Mandatory seat belt laws, their enforcement and appropriate public awareness campaigns have been shown to 
be very effective in increasing rates of seat belt wearing [4]. Reducing stress, enhancing psychological and physiological health status greatly reduced the road traffic accidents. Physical exercise was also important to improve safety [12]. The work related stress and smoking affected the life style of drivers and it was significantly associated with the safety of road traffic among drivers [13].

There are different observations [14-20] and selfreported studies [10, 21-25] on seat belt use out of Ethiopia. But in the case of Ethiopia, little was known about the use of the seat belt and factors that affect using seat belt among drivers. So, the aim of this study was to assess the magnitude of seat belt use practice and associated factors among taxi and minibus drivers.

\section{Main text}

\section{Study design and study area}

Cross-sectional study was employed to assess seat belt use and associated factors among drivers in North Gondar Zone. In 2016 there were 453 mini buses and 282 taxies registered under the North Gondar Road \& Transport Authority.

\section{Sampling technique}

The list of minibus was taken from North Gondar Road and Transport office and list of taxies from two taxi associations. Then, sampling frame was prepared and simple random method was employed for selection. Total of 262 minibus and 163 taxi drivers were selected for data collection.

\section{Data processing and analysis}

Data were entered into Epinfo version 3.5.1 and exported to SPSS for analysis. Findings are summarized by tables and texts. Bivariable analysis was done and variable with $\mathrm{P} \leq 0.2$ were entered to multiple logistic regression analyses. The strength of association was determined using odds ratio at $95 \%$ confidence interval and $\mathrm{P}<0.05$; the Hosmer-Lemeshow statistic was used to check the model of goodness.

\section{Results}

Socio-demographic and behavioral characteristics of drivers A total of 425 drivers were participated in the study of which $38.4 \%$ were taxi drivers and $61.6 \%$ minibus drivers and there was only one female participant. About $86 \%$ of the drivers were Christians and the rest (13\%) are Muslims. More than half $(56.7 \%)$ of the drivers served for 5 years and above; and the rest $(43.3 \%)$ served for less than 5 years in deriving. Most of the drivers $(55.3 \%)$ were aged $25-30$ years and $17.2 \%, 15.5 \%$, and $12 \%$ of the participants were aged $31-36,19-24$ and $\geq 37$ years respectively. With regard to the educational status, $37.2 \%$ of the drivers completed grades 9-10, 25.2\% completed grades $11-12$ and about $20 \%$ of them took vocational training and above. The number of participants who were married and single was comparable. There were 91 (21.4\%) drivers who use alcohol and the rest (78.6\%) were non-alcoholic.

\section{Knowledge of drivers about the use of seat belts}

The knowledge questions were scored, with a mean score of $5.82 \pm 1.22$. The respondents scored mean and above (5-7 points) were considered as having a good knowledge and below the mean ( $0-4$ points) was considered as having poor knowledge. About $61.4 \%$ of respondents have good knowledge of using seat belt while the remaining $38.6 \%$ respondents score poor knowledge.

The majority of the drivers (98.1\%) thought the Ethiopian seat belt law had been made to minimize injuries, 95.8\% said to prevent casualties, $92.5 \%$ said to safeguard vehicle occupants, $29.9 \%$ said to generate revenue for the government and $22.8 \%$ to beautify the vehicle while $2.8 \%$ of drivers did not know about the law. Concerning the category of people who must use seat belts; $76.0 \%$ drivers said everybody should use, 9.2\% said drivers only, $14.6 \%$ said drivers and front sitters and $0.2 \%$ of them said passengers only. Almost comparable number of participants reported that seat belt should be fastened before and after the engine is ignited (Table 1).

\section{Self-reported seat belt use practice}

The possible responses for "how often do you wear a seat belt when driving a car?" were, never wear seat belt, sometimes, most of the time and always. For the purpose of analysis, "most of the time and always" were denoted as "users" and never and sometimes were grouped as "non users" and finally, $69.6 \%$ were users and $30.4 \%$ were non users.

Type of car, marital status, educational level and alcohol drinking were associated $(\mathrm{P} \leq 0.2)$ with seat belt use in bivariable analysis and transferred to multiple logistic regression. However, type of car, marital status, educational level remained significant $(\mathrm{P}<0.05)$. Taxi drivers were more likely to use seat belt than minibus drivers, it is about two times higher (AOR $=1.99,95 \%$ CI 1.25 , 3.19). Married drivers were almost three times more likely to use seat belts compared to separated and cohabited drivers (AOR $=2.92,95 \% \mathrm{CI} 1.12,7.60)$ and drivers who attended vocational school and above were 2.14 times higher to use seat belt than those who attended grade eight and below (AOR $=2.14,95 \%$ CI 1.01, 4.52) (Table 2).

\section{Reasons for using and not using seat belt by the drivers}

Drivers who were using seat belt were requested to forward their reasons for using seat belts. Most of $(79.3 \%)$ 


\begin{tabular}{|c|c|}
\hline Knowledge questions & $\mathrm{N}(\%)$ \\
\hline \multicolumn{2}{|l|}{ Reasons for setting seat belt law } \\
\hline \multicolumn{2}{|l|}{ To minimize injuries } \\
\hline Yes & $417(98.1)$ \\
\hline No & $8(1.9)$ \\
\hline \multicolumn{2}{|l|}{ To prevent casualties } \\
\hline Yes & 407 (95.8) \\
\hline No & $18(4.2)$ \\
\hline \multicolumn{2}{|l|}{ To safeguard vehicle occupants } \\
\hline Yes & $393(92.5)$ \\
\hline No & $32(7.5)$ \\
\hline \multicolumn{2}{|c|}{ To generate revenue for government } \\
\hline Yes & $127(29.9)$ \\
\hline No & $298(70.1)$ \\
\hline \multicolumn{2}{|l|}{ To beautify the vehicle } \\
\hline Yes & $97(22.8)$ \\
\hline No & $328(77.2)$ \\
\hline \multicolumn{2}{|l|}{ Do not know about the law } \\
\hline Yes & $12(2.8)$ \\
\hline No & $413(97.2)$ \\
\hline \multicolumn{2}{|c|}{ Category of people to use safety belt } \\
\hline Everybody/passengers & $323(76.0)$ \\
\hline Drivers only & $39(9.2)$ \\
\hline Drivers and front sitters & $62(14.6)$ \\
\hline Passengers only & $1(0.2)$ \\
\hline \multicolumn{2}{|c|}{ The right time to fasten safety belt } \\
\hline Before igniting the engine & $219(51.5)$ \\
\hline After igniting the engine & $191(44.9)$ \\
\hline While driving on the road & $15(3.5)$ \\
\hline Before igniting the engine & $219(51.5)$ \\
\hline
\end{tabular}

the drivers said that seat belts could save lives, $4.2 \%$ stated that they wear seat belt because they simply heard it from mass media promotion, $29.6 \%$ reasoned that the presence of stiffer penalties for non-compliance with the seat belt law, $4 \%$ because there is an alarm system in the car and $5.9 \%$ of them were wearing seat belts as it was habit for them. Similarly, drivers who didn't use seat belt were asked why and not believing in seat belt safety (18.4\%), wasting time to wear seat belt (18.40\%) and discomforts with the seat belts $(7.80 \%)$ were the most common reasons for not using seat belt (Table 3 ).

\section{Discussion}

The use of seat belt in the current study was only $69.6 \%$ which is relatively similar to studies in Russia (55\%) [24] and USA (59.0\%) [21]. The seat belt use rate is higher than studies on taxi drivers of Beijing (7.7\%) [17], Thailand
(28.46\%) [20], Nigeria (18.9\%) [19], West Indies (31.6\%) [26] and Armenia (24\%) [22]. However, it was lower than a study among vehicle drivers in Nigeria (80\%) [23]. Using seat belts in North Gondar is lower, which has serious implications on safety so significant effort must be made to improve the use of seat belts in order to reduce morbidity and mortality from injuries. By effectively coupling media and enforcement campaigns, significant increase in seat belt usage must be achieved. The mediabased approach for education and outreach on the use of seat belts was effective in increasing the public's awareness of the campaign in Nevada [27]. Therefore, different training strategies at bus stations and bus stops should be designed and applied to promote and/or encourage the use of seat belt.

In the current study, both age and drinking alcohol didn't predict the practice of seat belt use. This might be because of the nature of the study; difference in sampling, sample size and/or the difference on how participants perceive drinking alcohol. Alcohol impairs the reaction time of drivers and their ability to estimate risks and it is considered to be serious violation of traffic law [28] and finding from Thiland and America showed that seat belt use rate among drinkers was lower [21, 29, 30]. In addition, another American study found that older drivers were more likely to use belts compared to young drivers [31] and similarly, in the case of Ontario seat belt use increased with aging [32]. Regarding aging, the current finding was consistent with reports from West Indies [33], Nigeria [15], Russia [24] and Thai [20].

There married drivers used seat belt more than separated and cohabited drivers (AOR $=2.915,95 \%$ CI 1.118, 7.601). This is comparable with finding from West Indian study [33]. This can be explained by the fact that the married ones have additional responsibilities for their families and more likely to respect road safety measures and precautions.

In this study, more taxi drivers were using seat belts than bus drivers did (AOR $=1.998,95 \%$ CI 1.250, 3.192). Studies elsewhere also found similar reports; in Nigeria [15], Nanjing and Zhoushan, China [15] and Nanjing, China [18] taxi drivers were more likely to use seat belts compared to bus and pickup drivers. Traffic laws are less emphasized in roads outside cities due to limited resources to control [34]. In the same way, in Utah drivers in urban locations and those driving on the interstate were more likely to wear seat belt [14] and also Malaysian car drivers in city center areas were more likely to wear seat belts compared to those driving outside city [34].

Many findings from various studies showed that educational level of drivers was significantly associated with using seat belt. Drivers who attended vocational school and above used seat belt more than those who attended 
Table 2 Bivariable and multple logistic regression analyses of factors associated with seat belt use among minibus and taxi drivers, Gondar, Ethiopia, 2016

\begin{tabular}{|c|c|c|c|c|c|c|}
\hline \multirow[t]{2}{*}{ Variable } & \multicolumn{2}{|c|}{ Seat belt use } & \multirow[t]{2}{*}{ CR $(95 \% \mathrm{Cl})$} & \multirow[t]{2}{*}{ P-value } & \multirow[t]{2}{*}{ AOR $(95 \% \mathrm{Cl})$} & \multirow[t]{2}{*}{ P-value } \\
\hline & Users & Non users & & & & \\
\hline \multicolumn{7}{|l|}{ Car type } \\
\hline Taxi & 129 & 34 & $2.16(1.37,3.39)$ & 0.001 & $1.99(1.25,3.19)$ & 0.004 \\
\hline Minibus & 167 & 95 & & & & \\
\hline \multicolumn{7}{|l|}{ Marital status } \\
\hline Married & 138 & 52 & $2.65(1.04,6.75)$ & 0.040 & $2.92(1.12,7.60)$ & 0.029 \\
\hline Single & 148 & 67 & $2.21(0.88,5.56)$ & 0.092 & $2.29(0.89,5.95)$ & 0.087 \\
\hline Others $^{\mathrm{a}}$ & 10 & 10 & & 0.116 & 1.00 & 0.080 \\
\hline \multicolumn{7}{|l|}{ Age (in years) } \\
\hline $19-24$ & 51 & 15 & 1.00 & 0.099 & & \\
\hline $25-30$ & 155 & 80 & $0.57(0.30,1.08)$ & 0.083 & & \\
\hline $31-36$ & 57 & 16 & $1.05(0.47,2.33)$ & 0.909 & & \\
\hline$\geq 37$ & 33 & 18 & $0.54(0.24,1.22)$ & 0.137 & & \\
\hline \multicolumn{7}{|l|}{ Education } \\
\hline$\leq$ Grade 8 & 49 & 27 & 1.00 & 0.016 & 1.00 & 0.059 \\
\hline Grade 9-10 & 100 & 58 & $0.95(0.54,1.68)$ & 0.860 & $0.914(0.51,1.64)$ & 0.762 \\
\hline Grade 11-12 & 78 & 29 & $1.48(0.79,2.79)$ & 0.224 & $1.41(0.74,2.69)$ & 0.303 \\
\hline Vocational and above & 69 & 15 & $2.54(1.22,5.26)$ & 0.012 & $2.14(1.01,4.52)$ & 0.046 \\
\hline \multicolumn{7}{|l|}{ Alcohol drinking } \\
\hline Yes & 69 & 22 & 1.00 & & & \\
\hline No & 227 & 107 & $0.68(0.39,1.15)$ & 0.150 & & \\
\hline \multicolumn{7}{|c|}{ Duration of driving service (years) } \\
\hline$<5$ & 130 & 54 & 1.00 & & & \\
\hline$\geq 5$ & 166 & 75 & $0.92(0.61,1.39)$ & 0.694 & & \\
\hline
\end{tabular}

a Separated and cohabited

Table 3 Self reported reasons for using and not using seat belt among minibus and taxi drivers, Gondar, Ethiopia, 2016

\begin{tabular}{llll}
\hline Reasons for not using seat belt & Frequency (\%) & Reasons for using seat belt & Frequency (\%) \\
\hline Frequent stops & 1.40 & Mass media promotion & 4.20 \\
Forgetting & 1.40 & Penalty for non compliance & 29.6 \\
It is norm in our culture & 3 & Saves life & 79.30 \\
Driving slowly & 5.20 & Alarm system is there in the car & 4 \\
Creates discomfort & 7.80 & It is habit & 5.90 \\
Not believe of its safety & 18.40 & & \\
Takes time to wear & 18.4 & & \\
\hline
\end{tabular}

grade eight and lower $(\mathrm{AOR}=2.140,95 \%$ CI 1.014, 4.519). Reports from West India [33] and Northwestern Nigeria showed that educational level was positively and significantly associated with wearing seat belt [26]. In USA, education was also markedly associated with using seat belt [35]. The compliance level of wearing belts increased with the level of education in Malaysian study [34]. This is worthy to consider as education always contributes to a positive change. The current finding contradicts with study from Russia where college degree drivers were found to have a significant negative association with using seat belt [24].

In the current study, common reasons for wearing seat belt were, "seat belt saves life" (79.3\%), "stiffer penalties for non-compliance" (29.6\%) and "wearing habit" (5.9\%). These reasons were comparable to reports from China [25], Russia [29], Quatar [36] and West India [33]. In many studies, drivers did not like seat belts because of 
discomfort, lack of knowledge, not believing in seat belt safety, forgetfulness and habit to wear were reported [25, $31,33,36]$. In concordance with the above studies, in the current study the main reasons given for lower use were "not believing in seat safety" (18.4\%), "seat belt takes time to wear" (18.4\%) and "creates discomfort" (7.8\%). These findings suggest that we still need promotion on using seat belt during licensing and on job training to enhance safety.

\section{Conclusion}

Despite the proven effectiveness of seat belt, its use was lower $(69.6 \%)$ in northern Gondar. The type of car, marital status and drivers' level of education were significantly associated with the practice of seat belt. Therefore, drivers should be encouraged to use seat belts when they are at work and during licensing.

\section{Limitation of the study}

As this is a self reported data, participants may over estimate themselves on using seat belts. The method of data collection is open to self-reported and social desirability bias that may affect the result. It is also difficult to appreciate gender based comparisons and a discussion as only one female participant was included in the sample.

\section{Abbreviations}

AOR: adjusted odds ratio; Cl: confidence interval; COR: crude odds ratio; SPSS: Statistical Package for the Social Science.

\section{Authors' contributions}

MK contributed to conception, title selection, design and draft of the study. BG assisted in the interpretation. HT was involved in the analysis and writing up of the report. All authors read and approved the final manuscript.

\section{Author details}

${ }^{1}$ Department of Public Health, College of Health Sciences and Referral Hospital, Aksum University, Aksum, Ethiopia. ${ }^{2}$ Department of Biomedical Sciences, College of Health Sciences and Referral Hospital, Aksum University, P.O.Box: 298, Aksum, Ethiopia.

\section{Acknowledgements}

We are grateful to the study participants, supervisors and data collectors. We are also thankful to North Gondar Road and Transport Authority, Gondar City Waliya Taxi Owners Public Transport Association and Gondar City Jan Taxi Association.

\section{Competing interests}

All contributing authors declare that they have no financial, political, academic or any other potential source of competing interests.

\section{Availability of data and materials}

All the data supporting the findings is available within the manuscript.

\section{Consent for publication}

Not applicable.

\section{Ethics approval and consent to participate}

The study has got ethical approval from the Research and Publication Office of University of Gondar then, permission was obtained from the North Gondar
Zone Road and Transport Office. After detailed explanation of the objective of the study to the participants, finally written informed consent was obtained.

Funding

The study is not funded.

\section{Publisher's Note}

Springer Nature remains neutral with regard to jurisdictional claims in published maps and institutional affiliations.

Received: 18 October 2018 Accepted: 19 February 2019

Published online: 22 February 2019

\section{References}

1. Peden $M$, et al. World report on road traffic injury prevention. Geneva: World Health Organization; 2004.

2. Murray CJ, Lopez AD. The global burden of disease: a comprehensive assessment of mortality and disability from diseases, injuries, and risk factors in 1990 and projected to 2020: summary. 1996.

3. Violence, et al. Global status report on road safety: time for action. Geneva: World Health Organization; 2009.

4. Ncube M, et al. Mortality in Africa: the share of road traffic fatalities. Abidjan: African Development Bank; 2013.

5. Eckersley W, Salmon R, Gebru M. Khat, driver impairment and road traffic injuries: a view from Ethiopia. Bull World Health Organ. 2010;88(3):235-6.

6. Abegaz T, et al. Effectiveness of an improved road safety policy in Ethiopia: an interrupted time series study. BMC Public Health. 2014;14(1):539.

7. Mekonnen FH, Teshager S. Road traffic accident: the neglected health problem in Amhara National Regional State, Ethiopia. Ethiop J Health Dev. 2014;28(1):3-10.

8. WHO. Proceedings of WHO meeting to develop a 5-year strategy for road traffic injury prevention [Geneva, Switzerland, 26-27 April 2001]. 2001.

9. Oladepo O, Onyema CR. Knowledge and attitude of safety belt use among professional drivers in a tertiary Nigerian institution. Int J Injury Control Saf Promot. 2011;18(1):57-64.

10. Oluyemi A. Seatbelt use survey: a case study. Pak J Soc Sci. 2007:4(6):774-7.

11. Taylor AH, Dorn L. Stress, fatigue, health, and risk of road traffic accidents among professional drivers: the contribution of physical inactivity. Annu Rev Public Health. 2006;27:371-91.

12. Useche $S A$, et al. Patterns on work-related stress and tobacco consumption in city bus drivers. SAGE Open. 2018;8(2):2158244018782336.

13. Cook $L$, Hoggins $J \mathrm{~L}$, Olson LM. Observed seatbelt usage among drivers of heavy commercial vehicles in Utah. Accid Anal Prev. 2008;40(4):1300-4

14. Iribhogbe PE, Osime CO. Compliance with seat belt use in Benin City, Nigeria. Prehosp Disaster Med. 2008;23(01):16-9.

15. Kulanthayan S, et al. Seat belt use among car users in Malaysia. IATSS Res. 2004;28(1):19-25.

16. Passmore J, Ozanne-Smith J. Seatbelt use amongst taxi drivers in Beijing, China. Int J Injury Control Saf Promot. 2006;13(3):187-9.

17. Routley $\mathrm{V}$, et al. Pattern of seat belt wearing in Nanjing, China. Injury Prevent. 2007:13(6):388-93.

18. Sangowawa A, et al. Use of seatbelts by vehicle occupants in University College Hospital, Ibadan. Nigeria. Annals of Ibadan Postgraduate Medicine. 2007;3(2):57-62

19. Siviroj $P$, et al. Non-seatbelt use and associated factors among Thai drivers during Songkran festival. BMC Public Health. 2012;12(1):608.

20. Briggs NC, et al. Driver and passenger seatbelt use among US high school students. Am J Prev Med. 2008;35(3):224-9.

21. Chekijian SA, Truzyan N. Practices, attitudes and perceptions toward road safety in Yerevan, Republic of Armenia. In: Annals of Advances in Automotive Medicine/Annual Scientific Conference. Association for the Advancement of Automotive Medicine. 2012.

22. Ismaila S, Akanbi O. Study on the use of seat belt by Nigerian drivers. Aust J Basic Appl Sci. 2010:4(3):494-7. 
23. Ma S, et al. Seat belt and child seat use in Lipetskaya Oblast, Russia: frequencies, attitudes, and perceptions. Traffic Injury Prevent. 2012;13(sup1):76-81.

24. Routley $\mathrm{V}$, et al. Attitudes to seat belt wearing and related safety features in two cities in China. Int J Injury Control Saf Promot. 2009;16(1):15-26.

25. Idris SH, et al. Factors affecting self-reported use of seat belt among commercial vehicle drivers in Gusau metropolis Zamfara State North-western Nigeria. Int J Injury Control Saf Promot. 2013;20(4):380-4.

26. Vasudevan $V$, et al. Effectiveness of media and enforcement campaigns in increasing seat belt usage rates in a state with a secondary seat belt law. Traffic Injury Prevent. 2009;10(4):330-9.

27. Eensoo D, et al. Predicting drunk driving: contribution of alcohol use and related problems, traffic behaviour, personality and platelet monoamine oxidase (MAO) activity. Alcohol Alcohol. 2005;40(2):140-6.

28. Beck LF, et al. Associations between sociodemographics and safety belt use in states with and without primary enforcement laws. Am J Public Health. 2007;97(9):1619.
29. Foss RD, Beirness DJ, Sprattler K. Seat belt use among drinking drivers in Minnesota. Am J Public Health. 1994;84(11):1732-7.

30. Kim K, Yamashita EY. Attitudes of commercial motor vehicle drivers towards safety belts. Accid Anal Prev. 2007;39(6):1097-106.

31. Sahai VS, et al. Factors associated with seat belt use: an evaluation from the Ontario Health Survey. Can J Public Health. 1997;89(5):320-4.

32. Olukoga A, Legall G, Odekunle A. Pattern of seat belt use by drivers in Trinidad and Tobago, West Indies. BMC Res Notes. 2011;4(1):201.

33. Routley $\mathrm{V}$, et al. China belting up or down? Seat belt wearing trends in Nanjing and Zhoushan. Accid Anal Prev. 2008;40(6):1850-8.

34. Helsing KJ, Comstock GW. What kinds of people do not use seat belts? Am J Public Health. 1977;67(11):1043-50.

35. Shaaban K. Young drivers' attitude regarding seat belt use in Qatar. Training. 2012;23(5):1

36. Shaaban K. Comparative study of road traffic rules in Qatar compared to western countries. Procedia-social Behav Sci. 2012:48:992-9.
Ready to submit your research? Choose BMC and benefit from:

- fast, convenient online submission

- thorough peer review by experienced researchers in your field

- rapid publication on acceptance

- support for research data, including large and complex data types

- gold Open Access which fosters wider collaboration and increased citations

- maximum visibility for your research: over $100 \mathrm{M}$ website views per year

At BMC, research is always in progress.

Learn more biomedcentral.com/submissions 